\title{
Detection of Sub Clinical Infection of Mycoplasma gallisepticum in Commercial Chicken by Indirect ELISA
}

\section{Shanmugasundaram Udhayavel, Tippichettypalayam Ramasamy Gopala Krishna Murthy, Vasudevan Gowthaman*, Kandasamy Senthilvel, Ganesan Sureshiumar}

\author{
Poultry Disease Diagnosis and Surveillance Laboratory, Namakkal - 637 002, Tamil Nadu Veterinary and Animal \\ Sciences University, India.
}

\begin{abstract}
Chronic Respiratory disease in Poultry is mainly caused by Mycoplasma gallisepticum (MG). It causes huge economic loss to the poultry industry. The present research work has been undertaken to know the sero-prevalence of MG in commercial layers in Namakkal region of Tamil Nadu, India. A total of 103 commercial layer sera samples from 6 commercial layer farms were subjected to indirect ELISA. From 103 sera samples, overall prevalence found $53.40 \%$ for commercial layer chickens. The highest (100\%) sero-prevalence of MG was recorded at 32 weeks and the lowest (0\%) was recorded at 68 weeks of commercial layer chicken. This study demonstrated high sero-prevalence of MG in Commercial Layers. Therefore, routine monitoring of the commercial layer farms for MG infection should be recommended and mycoplasma control programmes must be strictly adhered.
\end{abstract}

Keywords | Poultry, Mycoplasma gallisepticum, Seroprevalence, ELISA

Editor | Kuldeep Dhama, Indian Veterinary Research Institute, Uttar Pradesh, India.

Received | June 14, 2016; Accepted | July 10, 2016; Published | August 17, 2016

*Correspondence | Vasudevan Gowthaman, Poultry Disease Diagnosis and Surveillance Laboratory, Namakkal - 637 002, Tamil Nadu Veterinary and Animal Sciences University, India; Email: vetgowth@rediffmail.com

Citation | Udhayavel S, Murthy TRGK, Gowthaman V, Senthilvel K, Sureshkumar G (2016). Detection of sub clinical infection of Mycoplasma gallisepticum in commercial chicken by indirect ELISA. Adv. Anim. Vet. Sci. 4(8): 438-440.

DOI | Http://dx.doi.org/10.14737/journal.aavs/2016/4.8.438.440

ISSN (Online) | 2307-8316; ISSN (Print) | 2309-3331

Copyright (c) 2016 Udhayavel et al. This is an open access article distributed under the Creative Commons Attribution License, which permits unrestricted use, distribution, and reproduction in any medium, provided the original work is properly cited.

\section{INTRODUCTION}

A mong the respiratory diseases of poultry, Mycoplasmosis is a major one. Even though all the age groups of turkeys and chickens are susceptible to this disease, the occurrence of mycoplasmosis is higher in young birds when compare to adults (Ley and Yoder, 1997; Nunoya et al., 1995). It is mainly caused by Mycoplasma gallisepticum (MG) and Mycoplasma synoviae (MS). MG infection results in increase Feed conversion ratio, poor weight gain and high mortality in broiler and reduced egg production in layer chicken thereby it causes huge economic loss to the poultry industry (Kleven and Noel, 2008; Ley, 2008).

Flock testing and culling is the best control measure for MG infection (Ahmad et al., 2008). Diagnosis of MG can be done by microbial culture, serological tests and molecular methods (Jalilnia and Movassagh, 2011). But for detecting the subclinical infection in the flock serology is the best tool (Barua et al., 2006). Thus, the present study has been undertaken to know the seroprevalence of Mycoplasma gallisepticum in commercial layer chicken in Namakkal region of Tamil Nadu, India.

\section{MATERIALS AND METHODS}

From 6 commercial layer farms in Namakkal region of Tamil Nadu, a total of 103 layer birds were selected for screening against MG by indirect ELISA. The age group of the birds ranged from 32 to 68 weeks. Standard vaccination protocol against Marek's disease, Newcastle disease, IBD and Pox were followed in all the commercial layer birds. But all the birds were not vaccinated against MG. Blood samples were collected aseptically and processed for serum separation as per standard methods. Then the sera samples were used for the serological study.

MG antigen coated plate (BioChek,UK) was used for the 
detection of antibody by indirect ELISA test. As per the manufacturer instruction the ELISA test has been carried out and the $\mathrm{S} / \mathrm{P}$ ratio was calculated. If the $\mathrm{S} / \mathrm{P}$ ratio is $\leq 0.5$ the sample is considered as negative and $\mathrm{S} / \mathrm{P}$ ratio of $>0.5$ considered as positive i.e. vaccination or infection with MG.

\section{RESULTS AND DISCUSION}

The results of the sero-prevalence of MG in commercial layers are given in Table 1 . The highest (100\%) sero-prevalence of MG was recorded at 32 weeks and the lowest (0\%) was recorded at 68 weeks of commercial layer chicken. And overall seroprevalence of MG found $53.40 \%$ for commercial layer chickens.

Table 1: Sero-prevalence of MG antibody in commercial layer chicken by indirect ELISA

\begin{tabular}{llllll|} 
Farms & $\begin{array}{l}\text { Age } \\
\text { (weeks) }\end{array}$ & \multicolumn{2}{l}{$\begin{array}{l}\text { No. of sera } \\
\text { tested }\end{array}$} & $\begin{array}{l}\text { No. of +ve Positive } \\
\text { samples }\end{array}$ & $\begin{array}{l}\text { Overall } \\
\text { prevalence }\end{array}$ \\
\hline L1 & 35 & 13 & 12 & 92.31 & \\
L2 & 43 & 16 & 14 & 87.50 & \\
L3 & 50 & 29 & 14 & 48.27 & $53.40 \%$ \\
L4 & 32 & 13 & 13 & 100 & \\
L5 & 62 & 16 & 2 & 12.5 & \\
L6 & 68 & 16 & 0 & 0 & \\
\hline
\end{tabular}

Previous surveys from France, Italy, Egypt and Jordan reported varying prevalence of $84 \%, 31 \%, 60 \%$ and $73.5 \%$ of MG by indirect ELISA respectively in commercial layers (Kempf et al., 1997; Mary et al., 1991; Osman et al., 2009; Saad and Dirgham, 2008). Another survey in commercial layer chickens of Poland revealed $65.2 \%$ sero-positivity of MG antibodies (Alina et al., 2000).In Bangladesh, 45.1\% sero-prevalence of $\mathrm{MG}$ was found in layer chickens (Hossain et al., 2010). These above findings are concurrence with the present study and our results are very close in accordance with another finding obtained in India with a positivity rate of $54.4 \%$ (Reddy, 2014).

Regarding age-wise analysis, $100 \%$ prevalence of MG infection was seen in 32 weeks age group followed by $92.31 \%$ in 35 weeks layer chickens. In 68 weeks old layer chickens, the lowest sero-prevalence of $0 \%$ was found. It revealed that when the age increased the prevalence of MG infection has been decreased. Similar kinds of reports were obtained in Pakistan and Bangladesh (Ahmad et al., 2008; Hossain et al., 2010; Sarkar et al., 2005).

This denotes that the prevalence of Mycoplasma gallisepticum in commercial layers decreased with increasing age. Highest sero-prevalence in the younger age group, maybe due to laying stress of the birds which might made the birds more prone to subclinical MG infections, and lowest rate of prevalence maybe due to treatment that were used in flocks. The adult birds were treated prophylactically with antimycoplasmal drugs in the feed and drinking water. So the chances of mycoplasmal infection have been reduced, there by the prevalence of MG has been decreased in adult birds. In consequence, $M$. gallisepticum is prevalent in In$\mathrm{dia}$. Therefore, routine monitoring of the commercial layer farms for MG infection should be recommended. In future studies on the current topic are therefore recommended.

\section{ACKNOWLEDGMENT}

The authors acknowledge the help of Director, Centre for Animal Health Studies, TANUVAS, Chennai, India.

\section{CONFLICT OF INTEREST}

There exists no conflict of interest

\section{AUTHORS' CONTRIBUTION}

All authors contributed equally.

\section{REFERENCES}

-Ahmad A, Rabbani M, Yaqoob T, Ahmad A, Shabbir MZ, Akhtar F ( 2008). Status of IgG antibodies against Mycoplasma gallisepticum in non-vaccinated commercial poultry Breeder flocks. J. Anim. Plant Sci. 18: 61-63.

-Alina W, Michaland M, Julita W (2000). Infections with Mycoplasma gallisepticum/synoviae in serological examination. Med. Weter. 56(4): 240-244.

-Barua SR, Prodhan AM, Islam A, Chowdhury S (2006).Study on Mycoplasma gallisepticum in chickens in selected areas of Bangladesh. Bangl. J. Vet. Med. 4(2): 141-142.

-Hossain KMM, Hossain MT, Yamato I (2010). Seroprevalence of Salmonella and Mycoplasma gallisepticum infection in Chickens in Rajshahi and surrounding districts of Bangladesh. Int. J. Biol. 2(2): 74-80. http://dx.doi. org/10.5539/ijb.v2n2p74

-Jalilnia M, Movassagh MH (2011). A study on causes of poultry carcasses condemnation in East Azerbaijan province (North West of Iran) poultry slaughterhouse. Annals Biologic. Res. 2(4): 343-347.

-Kempf I, Gesbertand F, Guittet M (1997). Experimental infection of chickens with an atypical Mycoplasma gallisepticumstrain: Comparison of diagnostic methods. Res. Vet. Sci. 63(3): 211-213. http://dx.doi.org/10.1016/S00345288(97)90022-9

-Kleven SH, Noel NF (2008). Mycoplasma synoviae infection. In: Diseases of poultry, Iowa State University Press. USA. Pp. 845-856.

-Ley DH (2008). Mycoplasma gallisepticum infection. In: Diseases of poultry, Iowa State University Press. USA. Pp. 805-833.

- Ley DH, Yoder Jr HW (1997). Mycoplasma gallisepticum infection. In: Disease of Poultry, Iowa state University Press, USA. Pp: 194-207. 
- Mary B, Margaret L, Andrea E, Gary D (1991). Detection of antibodies to Mycoplasma gallisepticum in egg yolk versus serum samples. J. Clin. Microbiol. 29(12): 2901-2903.

- Nunoya T, Yagihashi T, Tajima M, Nagasawa Y (1995). Occurrence of kerato conjunctivitis apparently caused by Mycoplasma gallisepticum in layer chickens. Vet. Pathol. 32: 11-18. http://dx.doi.org/10.1177/030098589503200102

- Osman KM, Aly MM, Amin ZMS, Hasan BS (2009). Mycoplasma gallisepticum: an emerging challenge to the poultry industry in Egypt. Rev. Sci. Technique de L Office Int. Epizoot. 28(3): 1015-1023.

-Reddy MR (2014).Prevalence of Mycoplasma gallisepticum infection in indian poultry farms. In: Proceedings of the $2^{\text {nd }}$ International Conference on Animal \& Dairy Sciences, Hyderabad, India, 2014. Pp. 31.

-Saad G, Dirgham A (2008). The Use of Molecular Techniques in Isolation and Characterization of Mycoplasma gallisepticum from Commercial Chickens in Jordan. Int. J. Poult. Sci. 7(1): 28-35. http://dx.doi.org/10.3923/ijps.2008.28.35

- Sarkar SK, Rahman MB, Rahman M, Amin KMR, Khan MFR, Rahman MM (2005). Sero-Prevalence of Mycoplasma gallisepticum infection of Chickens in model breeder poultry farms of Bangladesh. Int. J. Poult. Sci. 4(1): 32-35. http:// dx.doi.org/10.3923/ijps.2005.32.35 